\title{
DETERMINASI KEMISKINAN PENDUDUK JAWA TENGAH 2013-2017
}

\author{
(Determination of Poverty in The Population of Central Java 2013-2017)
}

\section{Laeli Sugiyono', Maharanny Diwid Prasetyawati²}

\author{
BPS Provinsi Jawa Tengah ${ }^{1}$ \\ BPS Provinsi Jawa Tengah² \\ E-mail: laeli@bps.go.id
}

\begin{abstract}
ABSTRAK
Penelitian ini bertujuan menganalisis determinasi pengungkapan kemiskinan penduduk di Jawa Tengah. Penelitian menggunakan data sekunder berupa data panel gabungan data time series 2013-2017 dan data cross-sectiona/ kabupaten/kota. Analisis data menggunakan model regresi Ordinary Least Square (OLS) dan model Efek Tetap (Fixed Effect).

Penelitian menyimpulkan bahwa daterminasi kemiskinan penduduk di Jawa Tengah dapat diungkapkan melalui perubahan IPM, tingkat pengangguran terbuka (TPT), upah minimum kabupaten/kota (UMK), dan pertumbuhan ekonomi (PE). TPT sebagai variabel bebas berpengaruh signifikan positif, sedangkan IPM dan UMK berpengaruh signifikan negatif pada taraf nyata $5 \%$ terhadap kemiskinan penduduk sebagai variabel tidak bebas (dependent).
\end{abstract}

Kata kunci: kemiskinan penduduk, regresi panel, tingkat pengangguran terbuka, upah minimum.

\section{ABSTRACT}

This study aims to analyze the determination of disclosure of population poverty in Central Java. The study uses secondary data in the form of panel data as a combination of 2013-2017 times series data and city/district cross-sectional data. Data analysis used Ordinary Least Square (OLS) regression with Fixed Effect.

The study concluded that the determination of poverty in the population of Central Java can be expressed through changes in human development index, open unemployment rate, minimum wages of district/city, and economic growth. Open unemployment rate as an independent variable has a significant positive effect, whereas human development index and minimum wages have a significant negative effect on the $5 \%$ level of poverty of the population as dependent variable.

Keywords: poverty of population, panel regression, open unemployment rate, minimum wages

\section{PENDAHULUAN}

Pembangunan ekonomi pada dasarnya merupakan perwujudan proses multidimensi yang melibatkan perubahan struktur mendasar dalam barbagai hal, antara lain: sosial, sikap masyarakat, dan kelembagaan. Proses pembangunan yang terjadi misalnya adalah percepatan pertumbuhan ekonomi, pengurangan dan penanggulangan penduduk miskin dan ketimpangan sosial (Todaro, 2003).

Kemiskinan merupakan salah satu persoalan mendasar yang dihadapi oleh negara-negara berkembang di Indonesia (Yuwono, 2018). Kemiskinan diketahui sebagai permasalahan yang kompleks, dimana melibatkan faktor-faktor yang saling berkaitan, antara lain: tingkat pendapatan, kesehatan, pendidikan, akses terhadap barang dan jasa, lokasi geografis, gender dan kondisi lingkungan. Kompleksnya permasalahan kemiskinan ini, membuat upaya pengentasan kemiskinan akan terasa cukup sulit. Berbagai penanggulangan kemiskinan menjadi agenda penting pembangunan dalam mewujudkan kesejahteraan masyarakat. (Bappenas, 2000).

Secara umum, kemiskinan diartikan sebagai ketidakmampuan seseorang untuk memenuhi kebutuhan primer kehidupannya. Menurut Poerwadarminto (1976), secara harafiah kata miskin berarti tidak berharta benda. Kemiskinan merupakan suatu kondisi kehidupan serba kekurangan yang dialami seseorang sehingga tidak mampu memenuhi kebutuhan minimal kehidupannya. 
Standar minimal kebutuhan hidup ini berbeda satu daerah dengan daerah yang lain karena sangat bergantung pada kebiasaan/adat, fasilitas transportasi dan distribusi serta letak geografisnya.

Kuncoro (1997:103) menyatakan bahwa kemiskinan didefinisikan sebagai ketidakmampuan untuk memenuhi standar hidup atau dengan kata lain ketidakmampuan individu untuk memenuhi kebutuhan dasarnya. Kebutuhan dasar adalah kebutuhan yang sangat penting guna kelangsungan hidup manusia, baik yang terdiri dari kebutuhan atau konsumsi individu (makan, perumahan dan pakaian) maupun keperluan pelayanan sosial tertentu (air minum, sanitasi, transportasi, kesehatan dan pendidikan).

Berdasarkan latar belakang tersebut, maka perlu dianalisis determinasi pengungkapan kemiskinan penduduk di Jawa Tengah. Dengan diketahuinya variabel determinasi kemiskinan Jawa Tengah, maka strategi pembangunan yang dilakukan baik oleh pemerintah pusat pada umumnya, khususnya pemerintah daerah dalam mengurangi kemiskinan lebih tepat, efektif dan efisien.

\section{METODE}

\section{Analisis Data Panel}

Menurut Gujarati dan Dawn (2006), data panel atau yang disebut juga data longitudinal merupakan gabungan antara data cross section dan data time series. Data cross section adalah data yang dikumpulkan dalam satu waktu terhadap banyak individu, sedangkan data time series merupakan data yang dikumpulkan dari waktu ke waktu terhadap suatu individu. Metode data panel merupakan suatu metode yang digunakan untuk melakukan analisis empirik dengan perilaku data yang lebih dinamis.Ada 3 teknik pendekatan mendasar yang digunakan dalam menganalisis data panel:

\section{a. Model Pooled Least Square (Common Effect)}

Model ini dikenal dengan estimasi Common Effect yaitu teknik regresi yang paling sederhana untuk mengestimasi data panel dengan cara hanya mengkombinasikan data time series dan cross section. Model ini hanya menggabungkan kedua data tersebut tanpa melihat perbedaan antarwaktu dan individu sehingga dapat dikatakan bahwa model ini sama halnya dengan metode OLS (Ordinary Least Square) karena menggunakan kuadrat kecil biasa.

Dalam pendekatan ini hanya mengasumsikan bahwa perilaku data antar ruang sama dalam berbagai kurun waktu. Pada beberapa penelitian data panel, model ini seringkali tidak pernah digunakan sebagai estimasi utama karena sifat dari model ini yang tidak membedakan perilaku data sehingga memungkinkan terjadinya bias, namun model ini digunakan sebagai pembanding dari kedua pemilihan model lainnya.

\section{b. Model Pendekatan Efek Tetap (Fixed Effect)}

Pendekatan model ini menggunakan variabel boneka yang dikenal dengan sebutan model efek tetap (fixed effect) atau Least Square Dummy Variable (LSDV) atau disebut juga model Covariance.

Pada metode Fixed Effect, estimasi dapat dilakukan dengan tanpa pembobot ( $n$ o weighted) atau LSDV dan dengan pembobot (cross section weight) atau General Least Square (GLS). Tujuan dilakukannya pembobotan adalah untuk mengurangi heterogenitas antar unit cross section (Gujarati, 2004).

Penggunaan model ini tepat untuk melihat perubahan perilaku data dari masing-masing variabel sehingga data lebih dinamis dalam mengintrepetasi data. Pemilihan model antara Common Effect dengan Fixed Effect dapat dilakukan dengan pengujian Likelihood Test Ratio dengan ketentuan apabila nilai probabilitas yang dihasilkan signifikan dengan alpha maka dapat diambil keputusan menggunakan Fixed Effect Model.

\section{c. Model Pendekatan Efek Acak (Random Effect)}

Model data panel pendekatan ketiga yaitu model efek acak (random effect). Dalam model efek acak, parameter-parameter yang berbeda antardaerah maupun antarwaktu dimasukkan ke dalam error. Karena hal inilah, model efek acak juga disebut model komponen error (error component model). 
Dengan menggunakan model efek acak ini, maka dapat menghemat pemakaian derajat kebebasan dan tidak mengurangi jumlahnya seperti yang dilakukan pada model efek tetap. Hal ini berimplikasi parameter yang merupakan hasil estimasi akan menjadi semakin efisien. Keputusan penggunaan model efek tetap atau pun acak ditentukan dengan menggunakan Uji Hausman dengan etentuan apabila probabilitas yang dihasilkan signifikan dengan alpha maka dapat digunakan metode Fixed Effect, namun apabila sebaliknya maka dapat memilih salah satu yang terbaik antara model Fixed Effect dengan Random Effect.

\section{Spesifikasi Model Regresi Data Panel}

Analisis data dibatasi pada Ima variabel, yaitu variabel Kemiskinan (JPM), Indeks Pembangunan Manusia (IPM), Tingkat Pengangguran Terbuka (TPT), Upah Minimum Kota (UMK), dan Produk Domestik Regional Bruto (PDRB) yang diukur dengan Pertumbuhan Ekonomi (PE).

Secara ekonometrika, hubungan antara indeks pembangunan manusia, tingkat pengguran terbuka, upah minimum kabupaten kota dan produk domestik regional bruto dalam pertumbuhan ekonomi terhadap jumlah penduduk miskin di Provinsi Jawa Tengah dapat dianalisis dengan menggunakan persamaan berikut ini:

$$
I K M_{i t}=\alpha_{i t}+\beta_{1} I P M_{i t}+\beta_{2} U M K_{i t}+\beta_{3} T P T_{i t}+\beta_{4} L P E_{i t}+\varepsilon_{i t}
$$

dimana:

IKM = Persentase Kemiskinan Penduduk

IPM = Indeks Pembangunan Manusia

UMK = Upah Minimum Kabupaten/Kota

TPT = Tingkat Pengangguran Terbuka

$\mathrm{PE} \quad=$ Pertumbuhan Ekonomi

\section{Uji Kelayakan Model (Uji F)}

Uji keterandalan model atau uji kelayakan model atau yang lebih populer disebut sebagai uji $\mathrm{F}$ (uji simultan) merupakan tahapan awal mengidentifikasi model regresi yang diestimasi layak atau tidak. Layak (andal) disini maksudnya adalah model yang diestimasi layak digunakan untuk menjelaskan pengaruh variabel-variabel bebas terhadap variabel terikat. Nama uji ini disebut sebagai uji $\mathrm{F}$, karena mengikuti mengikuti distribusi $\mathrm{F}$ yang kriteria pengujiannya seperti One Way Anova.

Pengunaan software memudahkan penarikan kesimpulan alam uji ini. Apabila nilai prob. $\mathrm{F}$ hitung lebih kecil dari tingkat kesalahan/error (alpha) 0,05 (yang telah ditentukan) maka dapat dikatakan bahwa model regresi yang diestimasi layak, sedangkan apabila nilai prob. $\mathrm{F}$ hitung lebih besar dari tingkat kesalahan 0,05 maka dapat dikatakan bahwa model regresi yang diestimasi tidak layak.

\section{Uji Koefisien Regresi (Uji t)}

Uji t dalam regresi linier berganda dimaksudkan untuk menguji apakah parameter (koefisien regresi dan konstanta) yang diduga untuk mengestimasi persamaan/model regresi linier berganda sudah merupakan parameter yang tepat atau belum. Maksud tepat disini adalah parameter tersebut mampu menjelaskan perilaku variabel bebas dalam mempengaruhi variabel dependent. Parameter yang diestimasi dalam regresi linier meliputi intersep (konstanta) dan slope (koefisien dalam persamaan linier). Pada bagian ini, uji t difokuskan pada parameter slope (koefisien regresi) saja. Jadi uji t yang dimaksud adalah uji koefisien regresi.

\section{Uji AutoKorelasi}

Uji validitas model regresi persamaan data panel juga dilakukan terhadap kasus autokorelasi, yaitu menggunakan uji statistik d dari Durbin Watson dengan kriteria: (1) $1.65<\mathrm{DW}<2.35$ yang artinya tidak terjadi autokorelasi; (2) 1,21 < DW $<1,65$ atau 2,35 $<$ DW $<2,79$ yang artinya tidak dapat disimpulkan tetapi jika nilai DW > R-Square maka tidak patut terjadi auto korelasi; dan (3) DW $<1,21$ atau DW $>2,79$ yang artinya terjadi autokorelasi. Jika terjadi autokorelasi maka berimplikasi 
model yang dibentuk tidak handal dalam menjelaskan hubungan determinasi pengungkapan kemiskinan terhadap kemiskinan penduduk /jawa Tengah.

\section{Pemilihan Variabel Pokok \\ a. Kemiskinan}

Supriatna (1997:90) menyatakan bahwa kemiskinan adalah situasi yang serba terbatas yang terjadi bukan atas kehendak orang yang bersangkutan. Suatu penduduk dikatakan miskin bila ditandai oleh rendahnya tingkat pendidikan, produktivitas kerja, pendapatan, kesehatan dan gizi serta kesejahteraan hidupnya, yang menunjukkan lingkaran ketidakberdayaan. Kemiskinan bisa disebabkan oleh terbatasnya sumber daya manusia yang ada, baik lewat jalur pendidikan formal maupun nonformal yang pada akhirnya menimbulkan konsekuensi terhadap rendahnya pendidikan informal.

Emil Salim (dalam Supriatna, 1997: 82) mengemukakan ada 5 karakteristik penduduk miskin. Kelima karakterisktik penduduk miskin tersebut adalah: 1) Tidak memiliki faktor produksi sendiri, 2) Tidak mempunyai kemungkinan untuk memperoleh aset produksi dengan kekuatan sendiri, 3) Tingkat pendidikan pada umumnya rendah, 4) Banyak di antara mereka yang tidak mempunyai fasilitas, dan 5) Di antara mereka berusia relatif muda dan tidak mempunyai keterampilan atau pendidikan yang memadai.

Laeli Sugiyono dan Sriningsih (2019) menemukan 5 karakteristik utama, yaitu daerah tempat tinggal, gender, jenjang pendidikan, jumlah anggota rumah tangga dan status bekerja kepala rumah tangga, yang berpotensi menyebabkan kemiskinan rumah tangga di Jawa Tengah.

b. Indeks Pembangunan Manusia (IPM)

Definisi Indeks Pembangunan Manusia menurut Human Development Report (1990:10) adalah ide dasar untuk menciptakan pertumbuhan positif dalam bidang ekonomi, sosial, politik, budaya dan lingkungan serta perubahan dalam kesejahteraan manusia. Ide tersebut direpresentasikan dalam tiga dimensi dasar yaitu umur panjang yang sehat, pengetahuan dan penghidupan yang layak (Suhariyanto, 2017).

\section{c. Upah Minimum Kota (UMK)}

Definisi menurut Badan Pusat Statistik (2017) UMK merupakan upah minimum yang berlaku untuk daerah kabupaten/kota yang juga ditetapkan oleh gubernur atas rekomendasi Dewan Pengupahan Provinsi dan Bupati/Walikota. Pada penentuan UMK berdasarkan PP, mekanismenya terdiri dari 2 komponen yang sangat menentukan yaitu inflasi dan pertumbuhan ekonomi. Kedua komponen tersebut tergantung dengan perekonomian Indonesia yang tercatat oleh Badan Pusat Statistik.

\section{d. Produk Domestik Regional Bruto (PDRB)}

Definisi Produk Domestik Regional Bruto (PDRB) menurut Badan Pusat Statistik (2017) didefinisikan sebagai jumlah nilai tambah yang dihasilkan oleh seluruh unit usaha dalam suatu wilayah, atau merupakan jumlah seluruh nilai barang dan jasa akhir yang dihasilkan oleh seluruh unit ekonomi di suatu wilayah.

\section{HASIL DAN PEMBAHASAN}

\section{A. Regresi Determinan Kemiskinan Jateng}

Hasil regresi determinan kemiskinan penduduk Jawa Tengah adalah sebagai berikut:

$$
I K M_{i t}=42.52-0.42 I_{P} M_{i t}-0.02 U M K_{i t}+0.06 T P T_{i t}-0.83 .10^{-4} L P E_{i t}+\varepsilon_{i t}
$$

Tabel 1. memberikan informasi tentang hasil regresi panel dari determinan kemiskinan penduduk Jawa Tengah beserta angka statistik yang bersesuaian untuk keperluan baik pengujian heterokedasitas, pengujian validitas dan reliabilitas model regresi dan pengujian lainnya yang diperlukan.

Tabel 1. Hasil Regresi Panel dan Angka Statistik yang Bersesuaian untuk Keperluan Pengujian 


\begin{tabular}{ccccc}
\hline Variabel & Koefisien & Kesalahan Baku & Nilai Uji Statistik t & Probabilitas \\
\hline C & 42.51949 & 2.196744 & 19.35569 & 0.0000 \\
IPM & -0.421309 & 0.029021 & -14.51759 & 0.0000 \\
UMK & -.0 .022311 & 0.004763 & -4.684511 & 0.0000 \\
LPE & -0.000831 & 0.017511 & -0.047470 & 0.9622 \\
TPT & 0.055746 & 0.029215 & 1.908111 & 0.0581 \\
\hline R-square & 0.673229 & Mean dependent var & 0.540352 \\
Adj R-square & 0.665540 & STD dependent var & 0.531108 \\
SE of regression & 0.307163 & Sum square residu & 16.39208 \\
F Stat & 38.93656 & Durbin Watson Stat & 1.703553 \\
Prob (F-Stat) & 0.000000 & & \\
\hline
\end{tabular}

Sumber: hasil ouput pengolahan menggunakan E-views

Regresi determinan kemiskinan penduduk Jawa Tengah memiliki koefisien determinasi ( $R$ Square) 0,673229 dan nilai statistik $F$ adalah 38,93656 dengan nilai probabilitas $a=0,000000$. Ini berarti bahwa tingkat variasi dari variabel bebas secara bersama-sama dapat menjelaskan variabel tak bebas kemiskinan penduduk Jawa Tengaah sebesar 67,32 persen pada tingkat kepercayaan $99 \%$.

Hasil uji signifikansi terhadap variabel bebas ternyata variabel LPE dan TPT, dimana dengan uji statistik $t$, variabel LPE memiliki probabilitas 0.9622 yang melebih batas toleransi 0.025 sehingga terjadi multikolinearitas, oleh karenanya variabel LPE tidak signifikan dan dikeluarkan dari persamaan regresi.

Uji signifikansi secara parsial dengan uji t-statistik terhadap variabel bebas sebagai faktor dari model determinan kemiskinan Jawa Tengah dan arah koefisien regresi menunjukkan bahwa variabel IPM , UMK, dan TPT dengan nilai probabilitas dibawah 0.05 signifikan dalam menjelaskan perubahan kemiskinan penduduk Jawa Tengah pada taraf nyata $10 \%$ atau dengan tingkat kepecayaan $90 \%$.

Uji validitas model determinan kemiskinan Jawa Tengah selain menggunakan uji statistik student-t juga perlu diuji korelasi serial melalui uji statistik Durbin Waston (DW). Model ini memiliki nilai statistik DW $=1.703553$ berada pada interval $1.65<\mathrm{DW}<2.35$ yang artinya tidak terjadi autokorelasi. Jika terjadi autokorelasi maka berimplikasi model yang dibentuk tidak handal dalam menjelaskan hubungan determinan kemiskinan penduduk Jawa Tengah.

\section{B. Indeks Pembangunan Manusia}

Determinan kemiskinan penduduk Jawa Tengah dapat dijelaskan oleh angka indeks pembangunan manusia sesuai hasil regresi panel yang memiliki hubungan berkebalikan, yang berlaku secara seteris paribus, yaitu jika variabel penjelas lain yang berpengaruh terhadap kemiskinan penduduk Jawa Tengah dianggap konstan dan setiap terdapat kenaikan nilai IPM sebesar $10 \%$, maka kemiskinan penduduk turun sebesar 4.21309 persen. Meningkatnya kualitas manusia dari ukuran IPM dengan indikator agregat dari kesehatan, pendidikan dan paritas daya beli memang sangat relevan, sehingga setiap ada perubahan kenaikan nilai IPM yang signifikan akan memicu turunnya kemiskinan penduduk yang signifikan pula.

\section{Upah Minimum Kabupaten/Kota}

Determinan kemiskinan penduduk Jawa Tengah dapat dijelaskan oleh upah minimum kabupaten/kota sesuai hasil regresi panel yang memiliki hubungan berkebalikan, yang berlaku secara seteris paribus, yaitu jika variabel penjelas lain yang berpengaruh terhadap kemiskinan penduduk Jawa Tengah dianggap konstan dan setiap terdapat kenaikan upah minimum kabupaten/kota sebesar $10 \%$, maka kemiskinan penduduk turun sebesar 0.2311 persen. Elastisitas perubahan kemiskinan penduduk yang relative rendah akibat perubahan upah minimum kabupaten/kota dikarenakan kenaikan UMK hanya meliputi pendapatan upah buruh dari sektor 
industri yang secara proporsional tidak dominan sehingga meskipun ada kenaikan upah yang signifikan tidak serta merta dapat menurunkan kemiskinan penduduk.

\section{Tingkat Pengangguran Terbuka}

Determinan kemiskinan penduduk Jawa Tengah dapat dijelaskan oleh tingkat pengangguran terbuka sesuai hasil regresi panel yang memiliki hubungan searah, yang berlaku secara seteris paribus, yaitu jika variabel penjelas lain yang berpengaruh terhadap kemiskinan penduduk Jawa Tengah dianggap konstan dan setiap terdapat kenaikan tingkat pengangguran terbuka sebesar $10 \%$, maka kemiskinan penduduk naik sebesar 0.55746 persen. Elastisitas perubahan kemiskinan penduduk akibat perubahan tingkat pengangguran terbuka relatif rendah dikarenakan pengangguran dalam konteks tatanan rumah tangga di Indonesia tidak menyebabkan rumah tangga kehilangan pendapatan karena masih ada anggota rumah tangga yang lain yang masih bekerja sehingga meskipun ada kenaikan tingkat pengguran terbuka yang signifikan tidak serta merta menaikkan kemiskinan penduduk secara signifikan.

\section{KESIMPULAN}

Determinasi kemiskinan penduduk Jawa Tengah dalam kurun waktu 2013-2017 dapat dijelaskan oleh indeks pembangunan manusia, tingkat pengangguran terbuka, dan upah minimum kabupaten/kota. Hanya IPM yang signifikan menjadi determinan kemiskinan pada taraf kepercayaan 95 persen dan memiliki hubungan berkebalikan. UMK juga memiliki hubungan berkebalikan namun pada taraf kepercayaan 90 persen. Untuk TPT memiliki hubungan searah namun juga signifikan pada taraf kepercayaan 90 persen. Sementara itu, LPE tidak signifikan menjadi determinan kemiskinan baik pada taraf kepercayaan 95 maupun 90 persen.

Rekomendasi yang dapat diberikan yakni diperlukan langkah antisipatif dalam kerangka pengurangan kemiskinan penduduk di antaranya peduli dan giat dalam pembangunan kualitas sumber daya manusia. Upah minimum kabupaten/kota juga perlu diperhatikan untuk memacu kesejahteraan buruh yang berdampak pada pengurangan kemiskinan penduduk. Selain itu, diperlukan upaya menumbuhkembangkan peningkatan kesempatan kerja pada seluruh sector riil. Hasil LPE yang tidak signifikan dalam mempengaruhi kemiskinan menjadi sinyal awal bahwa pembangunan belum inklusif. Perlu dikaji secara lebih mendalam mengenai arah pembangunan agar dapat berdampak signifikan dalam upaya pengentasan kemiskinan.

\section{DAFTAR PUSTAKA}

Ahmad Dzakiyuddin dan Dany Adi Saputra. (2019). Determinasi Pengungkapan Jumlah Penduduk Miskin di Provinsi Jawa Tengah 2012-2016. Jurnal Ekonomi Bisnis Magister Akuntansi Fakultas Ekonomi dan Bisnis Universitas Sebelas Maret.

Badan Pusat Statistik. (2018). Angka dan Data Jumlah Penduduk Miskin di Provinsi Jawa Tengah 2012-2016. Badan Pusat Statistik. (2018). Indeks Pembangunan Manusia 2013-2017.

Bada Pusat Statistik. (2018). Produk Domestik Regionl Bruto Menurut Lapangan Usaha Provinsi Jawa tengah 2012-2017.

Badan Pusat Statistik. (2018). Jawa Tengah dalam Angka.

Gujarati, Damodar N dan Dawn C, Porter. (2006). Dasar-Dasar Ekonometrika. Jakarta: Salemba Empat.

Human Development Report. (1990). United Nations Development Programme (UNDP). Oxford University Press: New York.

Keputusan Gubernur Jawa Tengah. (2017). Upah Minimum Kabupaten Kota 2017. Keputusan Gubernur Jawa Tengah. (2016). Upah Minimum Kabupaten Kota 2016. Keputusan Gubernur Jawa Tengah. (2015). Upah Minimum Kabupaten Kota 2015. Keputusan Gubernur Jawa Tengah. (2014). Upah Minimum Kabupaten Kota 2014. Keputusan Gubernur Jawa Tengah. (2013). Upah Minimum Kabupaten Kota 2013.

Todaro, Michael, P. (2003). Economic Development. The George Washington University. United Nations. (2015). The Millennium Development Goals Report 2015. United Nations. NewYork. 